\title{
Analisa Sebaran Klorofil-a dan Kualitas Air di Perairan Pulau Sintok, Karimunjawa, Jawa Tengah
}

\author{
Muhammad Sababa Alhaq*, Agus Anugroho Dwi Suryoputro, Muhammad Zainuri, Muslim dan \\ Jarot Marwoto
}

\author{
Departemen Oseanografi, Fakultas Perikanan Ilmu Kelautan, Universitas Diponegoro \\ Jl. Prof. H. Sudarto, SH, Tembalang, Kota Semarang, Kode Pos 50275 Telp/fax (024) 7474698 \\ Email: *sababaelhaqq@gmail.com
}

\begin{abstract}
Abstrak
Pulau Sintok termasuk di bagian zonasi pariwisata yang mana terdapat beberapa kegiatan tertentu yang terjadi di wilayah Pulau Sintok. Setiap kegiatan tentunya akan berpengaruh terhadap tingkat kesuburan dan keberadaan biota perairan, terutama fitoplankton. Fitoplankton menjadi parameter utama dalam perubahan kualitas air suatu perairan dikarenakan fitoplankton merupakan biota pertama yang merespon perubahan kualitas perairan. Penelitian ini bertujuan untuk mengetahui kandungan dan distribusi klorofil-a dan kualitas perairan di Pulau Sintok. Pengambilan sampel dilakukan pada tanggal 28 - 30 November 2019. Sampel air untuk analisa klorofil a diambil pada permukaan air, Adapun data kualitas air diukur secara exsitu. Hasil penelitian dari konsentrasi klorofil-a di lokasi perairan Pulau Sintok, Karimun Jawa, Jawa Tengah memiliki nilai konsentrasi yang berkisar antara 0,1401348 - 0,9097467 (mg/m $\left.{ }^{3}\right)$.Berdasarkan data diperoleh sebaran klorofil - a yang berbentuk divergen dari stasiun 1 sampai stasiun 10 dengan perbedaan yang tidak cukup signifikan. Hasil pengukuran suhu berkisar antara $28,3{ }^{\circ} \mathrm{C}-29,5{ }^{\circ} \mathrm{C}$; pengukuran salinitas memiliki nilai konsentrasi yang berkisar antara $32 \%$ - $35 \%$; pengukuran kecerahan berkisar antara 73,18 dan $100 \%$; derajat keasaman (pH) memiliki nilai konsentrasi yang berkisar antara 7 hingga 7,15; oksigen terlarut memiliki nilai konsentrasi yang berkisar antara 4,9 mg/l - 5,6 mg/l. Hubungan antara klorofil-a dan parameter kualitas air yang diukur secara korelasi regresi menunjukkan adanya persebaran yang bersifat divergen.
\end{abstract}

Kata kunci : Klorofil-a, kualitas air, Pulau Sintok, Karimunjawa

\begin{abstract}
Sintok Island is included in the tourism zoning section where certain activities occur in the Sintok Island area. Each activity will certainly affect the level of fertility and the existence of aquatic biota, especially phytoplankton. Phytoplankton is the main parameter in changing water quality in waters because phytoplankton is the first biota to respond to changes in water quality. This study aims to determine the content and distribution of chlorophyll-a and the quality of waters in Sintok Island. Sampling was carried out on November 28-30 2019. Water samples for chlorophyll-a analysis were taken on the surface of the sea water, while the water quality data were measure in situ. The results of the study of the chlorophyll-a concentration in the waters of Sintok Island, Karimun Jawa, Central Java have a concentration value ranging from 0.1401348 - $0.9097467(\mathrm{mg} / \mathrm{m3})$. Based on the data, the distribution of chlorophyll-a is divergent from station 1. up to station 10 with an insignificant difference. The temperature measurement results range from $28.3^{\circ}$ $C-29.5^{\circ} \mathrm{C}$; salinity measurements have concentration values ranging from $32 \%$ - $35 \%$; brightness measurements ranged between 73.18 and 100\%; the degree of acidity $(\mathrm{pH})$ has a concentration value ranging from 7 to 7.15 ; Dissolved oxygen has a concentration value ranging from $4.9 \mathrm{mg} / \mathrm{l}-5.6 \mathrm{mg} / \mathrm{l}$. The relationship between chlorophyll-a and water quality parameters measured by regression correlation showed a divergent distribution.
\end{abstract}

Keywords : Chlorophyll-a, water quality, Sintok Island, Karimunjawa

\section{PENDAHULUAN}

Perairan Pulau Karimunjawa terbagi atas beberapa zona pemanfaatan, diantaranya adalah zona inti, zona budidaya, dan zona pariwisata. Masing-masing zona pemanfaatan tersebut memiliki kegiatan yang berbeda-beda sesuai dengan zona pemanfaatannya. Setiap kegiatan yang dilakukan di daerah tersebut akan mempengaruhi kualitas perairan, selanjutnya akan berpengaruh terhadap keberadaan biota perairan khususnya fitoplankton sebagai biota pertama yang akan merespon perubahan kualitas perairan tersebut (Suryanti, 2010). Tingkat produktivitas perairan atau kesuburan suatu perairan pesisir dapat dinilai dari karakteristik biologi maupun fisika-kimia terutama dari ketersediaan zat hara esensial (Sanusi, 2004). Menurut Nybakken (1992), faktor biologis yang mempengaruhi tingkat kesuburan suatu perairan adalah 
klorofil-a. Klorofil-a merupakan pigmen yang mampu melakukan fotosintesis dan terdapat di seluruh biota fitoplankton. Fitoplankton di dalam ekosistem perairan berperan sebagai pengubah zat-zat anorganik menjadi zat organik melalui proses fotosintesis, yang kemudian dapat menentukan produktivitas perairan.

Effendi (2003), menyatakan bahwa tingkat kesuburan suatu perairan dapat ditinjau dari faktor fisika - kimia yaitu keadaan suhu, salinitas, DO, $\mathrm{pH}$, dan kecerahan suatu perairan. Faktor fisika di wilayah pesisir meliputi arus, gelombang, pasang surut, sedangkan parameter kimia terdiri dari BOD (biological oxygen demand), COD (chemical oxygen demand) dan DO (dissolved oxygen). Proses-proses tersebut secara bersamaan terjadi dan mengakibatkan peningkatan kandungan nutrien (nitrat dan ortofosfat) di dalam perairan, yang pada tahap selanjutnya akan digunakan untuk proses fotosintesis. Sumber nutrien (nitrat dan ortofosfat) secara alamiah berasal dari perairan itu sendiri melalui proses-proses penguraian pelapukan ataupun dekomposisi tumbuh - tumbuhan, sisa biota mati dan buangan limbah baik limbah daratan seperti domestik, industri, pertanian dan limbah peternakan. Oleh adanya arus yang merupakan salah satu parameter oseanografi yang mempengaruhi persebaran dari klorofil - a dan nutrient lainnya. Berdasarkan hal tersebut maka perlu dilakukan penelitian mengenai studi kesuburan perairan dengan melihat distribusi kandungan klorofil-a dan kualitas air di wilayah perairan Pulau Sintok. Hal ini untuk mengetahui hubungan dari klorofil-a dan kualitas air, serta dapat dijadikan landasan informasi mengenai pengelolaan dan pemanfaatan perairan Pulau Sintok dan sekitarnya.

\section{MATERI DAN METODE}

Materi penelitian ini menggunakan dua jenis data yaitu data primer dan sekunder. Data primer terdiri dari data Klorofil-a dan data kualitas air yang meliputi suhu, salinitas, $\mathrm{pH}$, oksigen terlarut $(D O)$ dan kecerahan yang diukur pada tanggal 28 - 30 November 2019 di Perairan Pulau Sintok dengan 10 titik sampling. Data sekunder terdiri dari : data arus yang diambil dari data penelitian oleh Elis et al (2020) yg berjudul Karakteristik Pasang Surut, Arus Laut dan Gelombang Berdasarkan Data Pengukuruan Acoustic Doppler Current Profiler (ADCP) di Perairan Pulau Cilik, Karimunjawa; Peta Administrasi Batas Provinsi Indonesia yang dikeluarkan oleh Badan Informasi Geospasial tahun 2013; Peta Esri, DigitalGlobe Tahun 2018 perekaman citra Satelit GeoEye tahun 2017.

\section{Metode Penentuan Titik Lokasi}

Metode penentuan lokasi pengukuran insitu menggunakan purposive sampling method, yaitu menentukan lokasi pengambilan sample berdasarkan pertimbangan-pertimbangan tertentu dari peneliti. Penentuan sepuluh titik lokasi di sekeliling pulau atas pertimbangan titik tersebut mewakili keseluruhan wilayah perairan di Pulau Sintok dengan interval kedalaman berkisar 5 hingga 20 meter.

Tabel 1. Koordinat Lokasi Pengambilan Sampel di Perairan Pulau Sintok

\begin{tabular}{ccl}
\hline Stasiun & Lintang Selatan & Bujur Timur \\
\hline Stasiun 1 & $-5^{\circ} 46.602^{\prime} \mathrm{S}$ & $110^{\circ} 30.567^{\prime} \mathrm{E}$ \\
\hline Stasiun 2 & $-5^{\circ} 46.510^{\prime} \mathrm{S}$ & $110^{\circ} 30.852^{\prime} \mathrm{E}$ \\
\hline Stasiun 3 & $-5^{\circ} 46.895^{\prime} \mathrm{S}$ & $110^{\circ} 31.079^{\prime} \mathrm{E}$ \\
\hline Stasiun 4 & $-5^{\circ} 47.155^{\prime} \mathrm{S}$ & $110^{\circ} 31.319^{\prime} \mathrm{E}$ \\
\hline Stasiun 5 & $-5^{\circ} 47.301 ' \mathrm{~S}$ & $110^{\circ} 31.0233^{\prime} \mathrm{E}$ \\
\hline Stasiun 6 & $-5^{\circ} 47.416^{\prime} \mathrm{S}$ & $110^{\circ} 30.756^{\prime} \mathrm{E}$ \\
\hline Stasiun 7 & $-5^{\circ} 47.191 ' \mathrm{~S}$ & $110^{\circ} 30.646^{\prime} \mathrm{E}$ \\
\hline Stasiun 8 & $-5^{\circ} 46.987 ' \mathrm{~S}$ & $110^{\circ} 30.520^{\prime} \mathrm{E}$ \\
\hline Stasiun 9 & $-5^{\circ} 46.861^{\prime} \mathrm{S}$ & $110^{\circ} 30.263^{\prime} \mathrm{E}$ \\
\hline Stasiun 10 & $-5^{\circ} 46.497 ' \mathrm{~S}$ & $110^{\circ} 30.307^{\prime} \mathrm{E}$
\end{tabular}




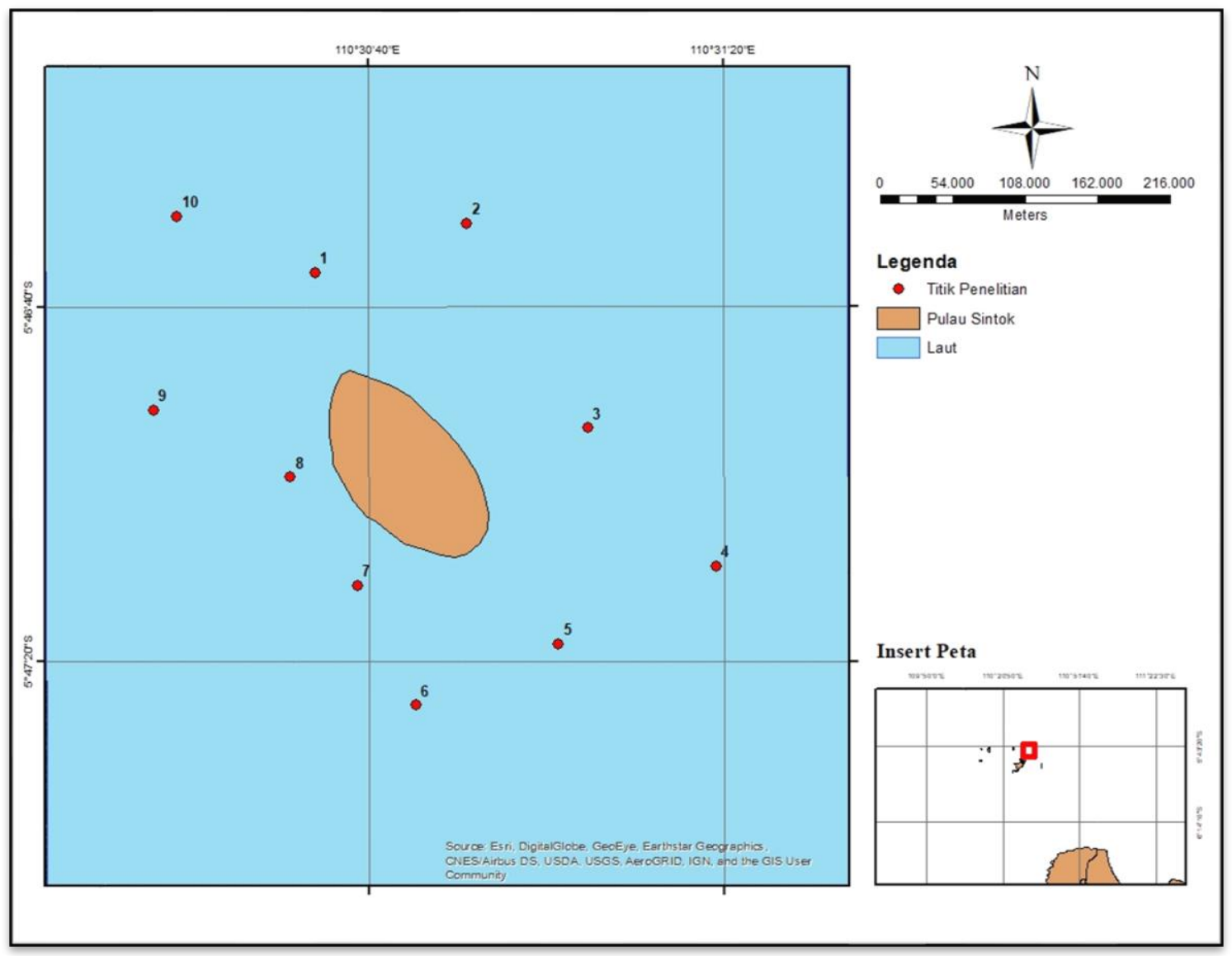

Gambar 1. Peta Titik Lokasi Stasiun Penelitian, Pulau Sintok, Karimunjawa, Jawa Tengah

\section{Metode Pengambilan Data Sampel Klorofil-a}

Pengukuran data lapangan ini dilakukan di Perairan Pulau Sintok, Karimunjawa, Jawa Tengah pada tanggal 28 - 30 November 2019 pukul 09.00 - 13.00 WIB. Sampel klorofil-a diambil secara horisontal mengunakan ember, kemudian dimasukkan kedalam botol sampel $1500 \mathrm{ml}$ dan disimpan ke dalam kotak pendingin (coolbox).

\section{Metode Pengambilan Data Kualitas Air}

Pengukuran data kualitas air di Perairan Pulau Sintok, Karimunjawa, Jawa Tengah pada tanggal 29 November 2019 pukul 09.00 - 13.00 WIB. Sampel yang diukur meliputi suhu, pH, DO, salinitas dan kecerahan. Paremeter suhu, $\mathrm{pH}, \mathrm{DO}$, dan salinitas diukur menggunakan water quality checker. Parameter kecerahan diukur menggunakan secchi disk di 10 titik sampling dengan melakukan pengulangan pengukuran sebanyak 3 kali lalu dihitung menggunakan rumus berikut (Koriyandi, 2016):

$$
I=\frac{\left(\frac{\mathrm{H}_{1}+\mathrm{H}_{2}}{2}\right)}{\mathrm{H}_{\text {total }}} \times 100 \%
$$


Keterangan :

I $\quad$ : Kecerahan perairan $(\%)$

H1 : kedalaman secchi disk hingga tak nampak (meter)

H2 : kedalaman secchi disk nampak (meter)

Htotal : kedalaman total (meter)

\section{Analisis Klorofil-a di Laboratorium}

Analisa klorofil-a dilakukan di laboratorium Tropical Marine Biodiversity, Universitas Diponegoro. Sampel klorofil-a disaring menggunakan kertas saring berukuran pori $0,42 \mu \mathrm{m}$ Hasil penyaringan disimpan dalam lemari pendingin bersuhu $5^{\circ} \mathrm{C}$, kemudian diberi larutan aseton $90 \%$ untuk melarutkan pigmen klorofil-a. Pigmen yang telah diekstrak kemudian diletakkan pada kuvet dan ditambahkan $0.1 \mathrm{ml} \mathrm{N}$ HCL. Setelah itu diukur dengan menggunakan spektrofotometer pada panjang gelombang $630 \mathrm{~nm}, 645 \mathrm{~nm}$, dan $665 \mathrm{~nm}$ (Nuzapril et al., 2017).

Nilai konsentrasi klorofil-a dihitung menggunakan rumus (APHA 2012):

$$
\text { Chl-a }=\underline{C a \times V a}
$$

$$
V \times \mathrm{d}
$$

Keterangan:

$$
\begin{array}{ll}
\text { Chl-a } & =\text { Kandungan klorofil-a } \\
\mathrm{Ca} & =11,85 \mathrm{E}_{664}-1,54 \mathrm{E}_{647}-0,08 \mathrm{E}_{630} \\
\mathrm{Va} & =\text { Volume aseton }(\mathrm{ml}) \\
\mathrm{V} & =\text { Volume sampel air disaring }(\mathrm{L}) \\
\mathrm{d} & =\text { Diameter cuvet } \\
\mathrm{E} & =\text { Penyerapan pada panjang gelombang yang bersangkutan }
\end{array}
$$

\section{Analisis Hasil Pola Sebaran dan Hubungan Klorofil -a dengan Kualitas Air}

Hasil persebaran klorofil-a, kualitas air dan arus menggunakan software ArcGIS 10.3. Persebaran klorofil-a dan kualitas air memperlihatkan bagaimana pola yang terjadi saat pengambilan sampel. Analisis hubungan klorofil-a dengan kualitas air disajikan dalam bentuk korelasi regresi dan overlay. Peta sebaran klorofil-a dengan kualitas air di overlay menggunakan software ArcGIS akan memperlihatkan pola yang konvergen atau divergen. Korelasi regresi data klorofil-a dan kualitas air dihitung menggunakan menggunakan software Microsoft Excel 2013 untuk melihat pola hubungan keduanya.

\section{HASIL DAN PEMBAHASAN}

\section{Hasil Konsentrasi Klofil-a}

Kandungan Klorofil - a di 10 stasiun pengamatan perairan Pulau Sintok, Karimunjawa berkisar antara $0,1401348-0,9097467(\mathrm{mg} / \mathrm{l})$ hal ini menunjukkan bahwa kandungan klorofil - a pada perairan Pulau Sintok ini termasuk dalam kategori oligotrofik. Kandungan klorofil - a $<0,2(\mathrm{mg} / \mathrm{l})$ pada suatu perairan dikategorikan sebagai perairan oligotrofik, kategori tersebut berarti perairan masih bersih dan belum tercemar dari unsur hara yang berlebih, perairan masih bersih dan jernih, tidak dijumpai tanaman air yang berlebih dan rendahnya unsur hara (Zulfia dan Aisyah, 2013). Hal ini juga sesuai dengan pernyataan Effendi (2003) bahwa oligotrofik merupakan status trofik air yang mengandung unsur hara dengan kadar 
rendah. Status tersebut menunjukkan kualitas air masih bersifat alamiah belum tercemar dari sumber unsur hara.

Tabel 2. Konsentrasi Klorofil-a di perairan Pulau Sintok, Karimun Jawa

\begin{tabular}{cc}
\hline Stasiun & Konsentrasi klorofil $\mathbf{- a}(\mathbf{m g} / \mathbf{l})$ \\
\hline $\mathbf{1}$ & 0,8362848 \\
$\mathbf{2}$ & 0,2126319 \\
$\mathbf{3}$ & 0,9097467 \\
$\mathbf{4}$ & 0,281544 \\
$\mathbf{5}$ & 0,6911165 \\
$\mathbf{6}$ & 0,45052 \\
$\mathbf{7}$ & 0,8918112 \\
$\mathbf{8}$ & 0,8671664 \\
$\mathbf{9}$ & 0,5778822 \\
$\mathbf{1 0}$ & 0,1401348 \\
\hline
\end{tabular}

(Sumber Data: Data Survei Lapangan 2019)

\section{Hasil Konsentrasi Kualitas Air}

Hasil pengukuran parameter kualitas air menunjukkan bahwa perairan Pulau Sintok masih meiliki kualitas perairan yang baik untuk menunjang kehidupan ekosistem didalamnya, yang tertera di Tabel 3:

Tabel 3. Nilai Konsentrasi Kualitas Air

\begin{tabular}{ccccccc}
\hline No & Stasiun & $\begin{array}{c}\text { DO } \\
(\mathbf{m g} / \mathbf{l})\end{array}$ & suhu $\left({ }^{\circ} \mathbf{C}\right)$ & $\begin{array}{c}\text { salinitas } \\
(\mathbf{\% o})\end{array}$ & $\mathbf{p H}$ & $\begin{array}{c}\text { kecerahan } \\
(\mathbf{\%})\end{array}$ \\
\hline 1 & 1 & 5.4 & 29 & 32.3 & 7.15 & 100 \\
\hline 2 & 2 & 5.09 & 28.5 & 34.7 & 7 & 100 \\
\hline 3 & 3 & 5.6 & 29.5 & 32.9 & 7.14 & 100 \\
\hline 4 & 4 & 5.05 & 28 & 34.7 & 7 & 100 \\
\hline 5 & 5 & 5.4 & 29 & 33.3 & 7.14 & 100 \\
\hline 6 & 6 & 5.1 & 28 & 33 & 7.1 & 100 \\
\hline 7 & 7 & 5.5 & 29.4 & 32 & 7.15 & 100 \\
\hline 8 & 8 & 5.6 & 29 & 32.8 & 7.13 & 100 \\
\hline 9 & 9 & 5.4 & 29 & 33.6 & 7.08 & 100 \\
\hline 10 & 10 & 4.9 & 28.3 & 35 & 7 & 73.18 \\
\hline
\end{tabular}

\section{Mawar Arus}

Data arus diambil menggunakan instrument Accoustic Doppler Current Profiler (ADCP) pada total kedalaman 12 meter dibagi menjadi 6 layer yaitu pada kedalaman 2 meter, 4 meter, 6 meter, 8 meter, 10 meter, dan 12 meter. Pengukuran dilakukan selama 7 X 24 jam (2 April 2017 - 9 April 2017) dengan interval waktu 600 detik dan sample rate 300 detik.

Arah dan kecepatan arus yang terjadi di Perairan Karimunjawa menunjukan adanya pola arus yang bergerak 2 arah atau yang disebut dengan bi-directional current. Arah arus menunjukan pergerakan arah barat-barat daya $\left(200^{\circ}-270^{\circ}\right)$ dan arah timur $\left(70^{\circ}-90^{\circ}\right)$. Pada kedalaman $0-2$ meter, data arus 
menunjukkan pergerakan dominan ke arah timur dengan persentase $27.03 \%$ dan kecepatan arus $5 \mathrm{~cm} / \mathrm{det}$ $-30 \mathrm{~cm} /$ det, arah sebaliknya menuju barat $(32.03 \%)$ dan barat daya $(12.05 \%)$ dengan kecepatan arus berkisar $0 \mathrm{~cm} / \mathrm{s}-25 \mathrm{~cm} / \mathrm{s}$.

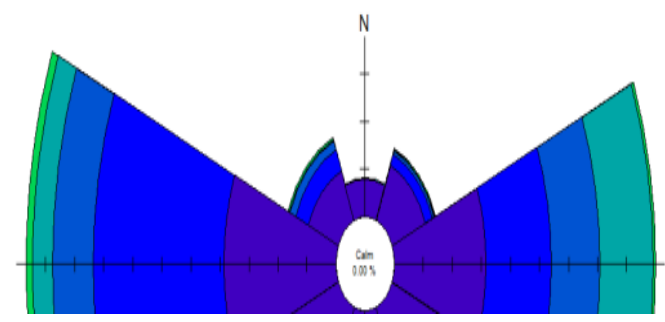

Gambar 2. Mawar Arus

\section{Hubungan Klorofil-a dengan Kualitas Air}

\section{Hubungan Klorofil-a dengan Suhu}

Hubungan klorofil-a dengan suhu terlihat signifikan. Hasil korelasi klorofil-a dengan suhu menunjukkan bahwa klorofil-a dipengaruhi oleh suhu yaitu sebesar $\mathrm{R}^{2}=0,7407$ (Gambar 3). Berdasarkan hasil overlay peta sebaran klorofil-a dan suhu, diperoleh bentuk pola divergen dari stasiun 1 sampai stasiun 10

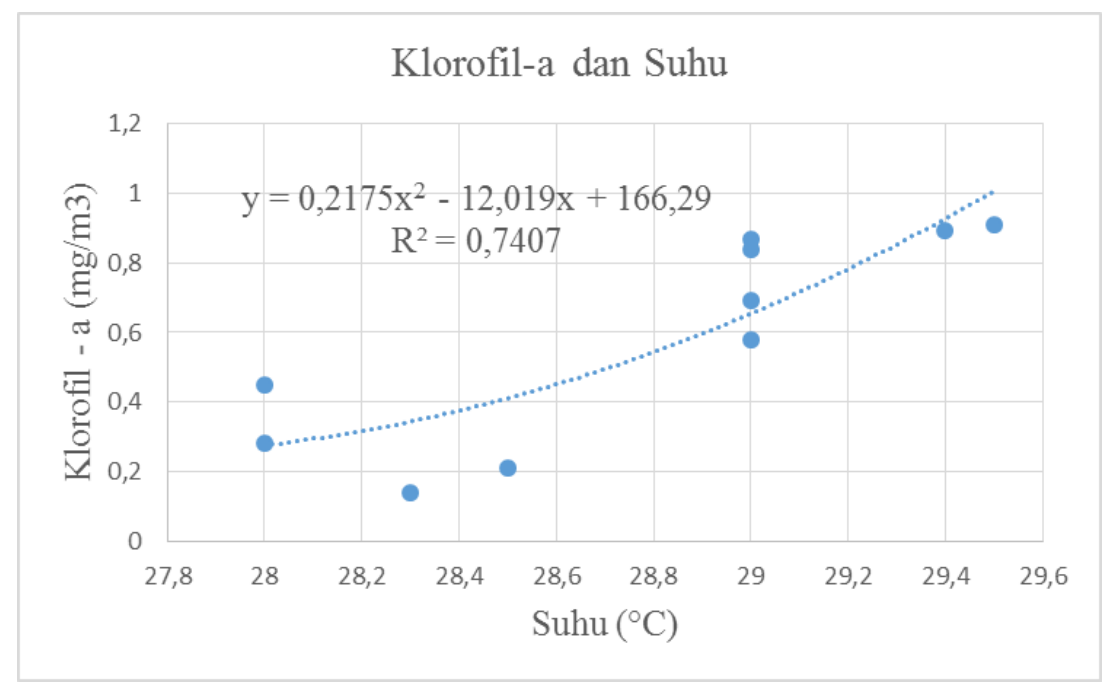

Gambar 3. Grafik Korelasi Klorofil-a dan Suhu

Hubungan klorofil - a dan suhu memiliki nilai korelasi regresi 0,7628 , hal ini menunjukkan persebaran klorofil - a di perairan Pulau Sintok sangat dipengaruhi oleh persebaran suhu. Hal tersebut berkesinambungan dengan pernyataan Hutabarat dan Evans (1986) bahwa suhu air rata rata berkisar antara $24-32^{\circ} \mathrm{C}$ sehingga pada kisaran tersebut plankton dapat tumbuh dan berkembang biak dengan baik. Berdasarkan hasil overlay stasiun 1 hingga 10 menunjukkan pola persebaran klorofil - a dan suhu memiliki kesamaan dan bersifat divergen. Persebaran klorofil - a dan suhu pada keseluruhan stasiun menunjukkan adanya pengaruh oleh kedalaman dan garis pantai. Riyono (2007) juga menyebutkan bahwa hubungan antara klorofil - a dan suhu menunjukkan pola sama terkait erat dengan kedalaman perairan dan kuantitas cahaya yang dapat di respon oleh kloroplas di dalam fitoplankton untuk berlangsungnya proses fotosintesis 


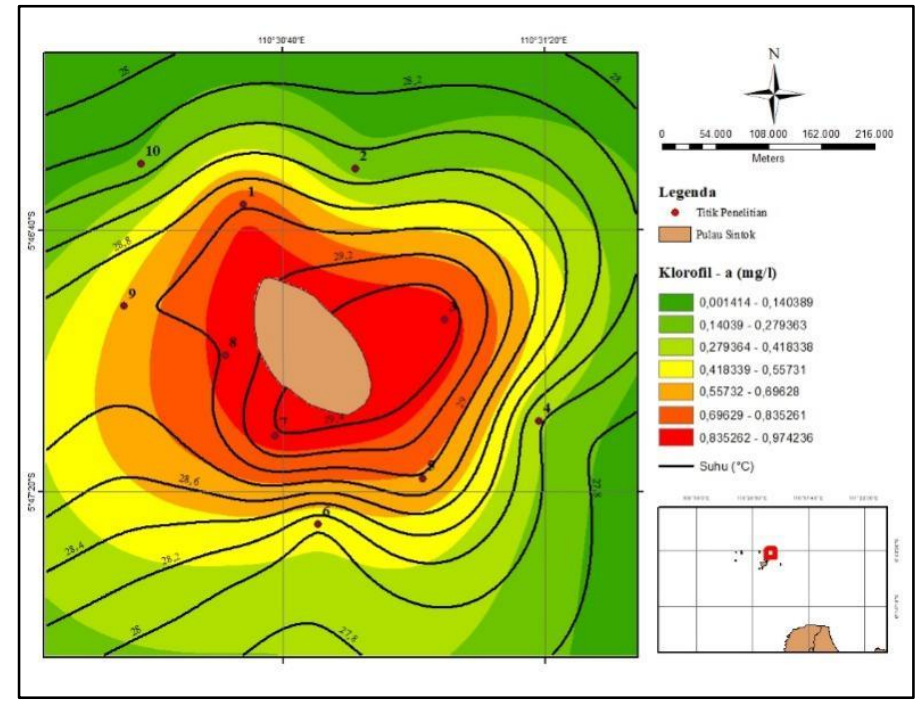

Gambar 4. Peta Overlay Klorofil-a dan Suhu

\section{Hubungan Klorofil-a dengan Salinitas}

Hubungan klorofil-a dengan salinitas terlihat signifikan. Hasil korelasi klorofil-a dengan salinitas menunjukkan bahwa klorofil-a dipengaruhi oleh salinitas sebesar $\mathrm{R}^{2}=0,8547$ (Gambar 5). Berdasarkan hasil overlay peta sebaran klorofil-a dan salintas, diperoleh bentuk pola divergen dari stasiun 1 sampai stasiun 10.

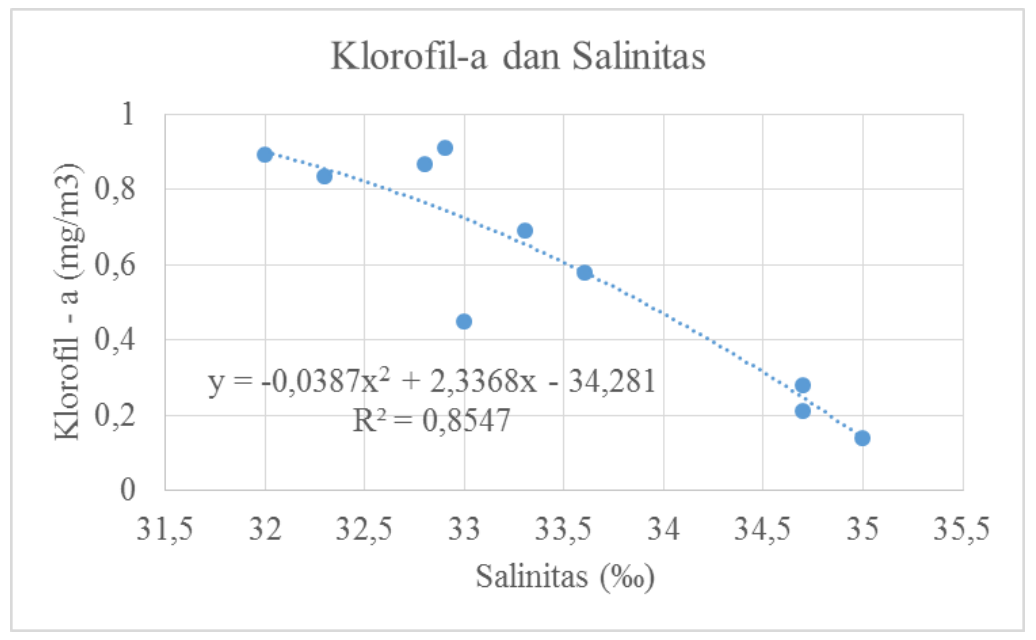

Gambar 2. Korelasi Klorofil-a dan Salinitas

Korelasi klorofil - a dan salinitas bernilai $\mathrm{R}^{2}=0,8547$ (gambar 5). Nilai regresi yang cukup tinggi menunujukkan bahwa persebaran klorofil - a dan salinitas memiliki hubungan erat namun bersifat negatif. Hadikusumah (2008) juga menyatakan dalam penelitiannya bahwa variasi salinitas akan berpengaruh pada laju fotosintesis, khususnya daerah pesisir yang dimana terdapat fitoplankton yang hanya bisa bertahan pada batasan-batasan salinitas yang rendah. Hal ini diperkuat dengan pernyataan Handayani et al,. (2005) bahwa salinitas yang rendah akan berkolerasi kuat dengan kenaikan klorofil-a dan pernyataan Utami et al., (2016) bahwa tingginya salinitas akan menghambat pertumbuhan perairan, termasuk terhambatnya proses fotosintesis fitoplankton. Pola persebaran klorofil - a dan salinitas bersamaan menunjukkan pola persebaran yang divergen (Gambar 6), yang artinya pola persebaran juga dipengaruhi oleh kedalaman perairan dan garis pantai. Hal ini sesuai dengan pernyataan Aziz (2007) bahwa distribusi salinitas di daerah pesisir dan muara hingga ke laut lepas menunjukkan kecenderungan salinitas yang terus bertambah. Penelitian ini 
membuktikan bahwa persebaran klorofil - a dan salinitas di Perairan Sintok berbanding terbalik namun dipengaruhi oleh faktor kimia - fisika, kedalaman dan garis pantai.

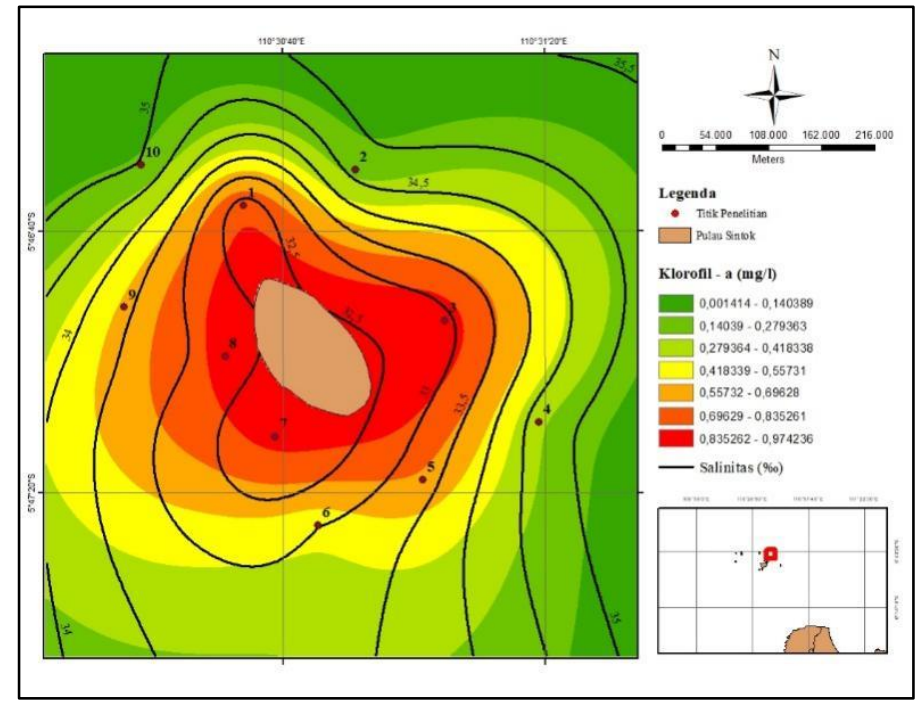

Gambar 3. Peta Overlay Klorofil-a dan Salinitas.

\section{Hubungan Klorofil-a dengan Kecerahan}

Hubungan klorofil-a dengan kecerahan terlihat signifikan. Hasil korelasi klorofil-a dengan kecerahan menunjukkan bahwa klorofil-a dipengaruhi oleh kecerahan yaitu sebesar $R^{2}=0,2758$ (Gambar 7). Berdasarkan hasil overlay peta sebaran klorofil-a dan kecerahan, diperoleh bentuk pola divergen dari stasiun 1 sampai stasiun 10 .

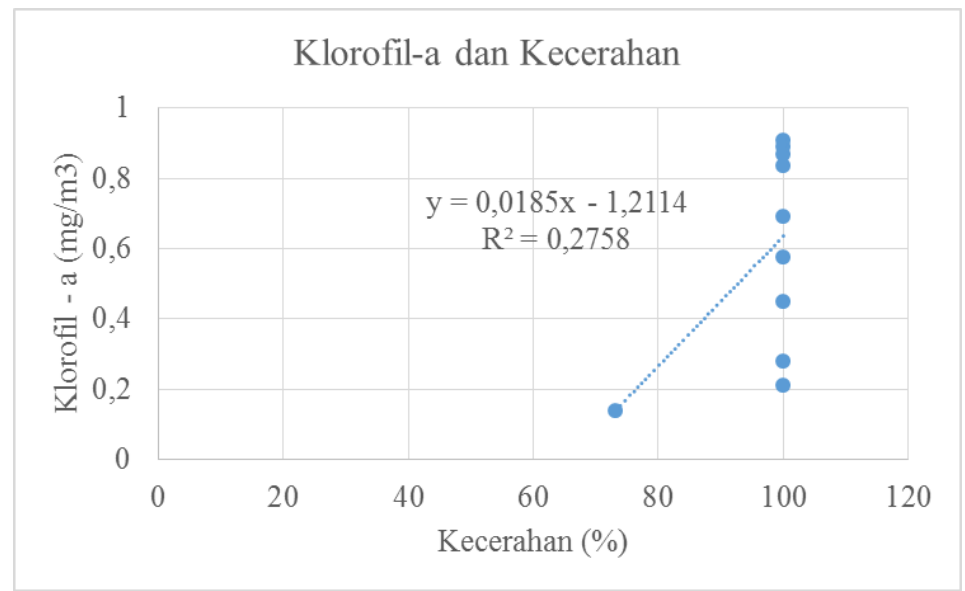

Gambar 4. Korelasi Klorofil-a dan Kecerahan.

Hubungan klorofil - a dan kecerahan di perairan Pulau Sintok memiliki nilai $\mathrm{R}^{2}=0,2758$ (Gambar 7). Nilai regresi yang cukup kecil namun bersifat positif tersebut diakibatkan kurangnya varietas nilai kecerahan pada 10 stasiun pengamatan. Hal tersebut dikarenakan kondisi perairan Karimunjawa yang masih jernih dan tingkat kontaminasi biotik dan abiotik yang sangat kecil. Hal ini diperkuat dengan pernyataan Nontji (2002) bahwa biota laut memerlukan air laut yang bersih, karena partikel-partikel yang terdapat di dalam air dapat menghalangi masuknya cahaya matahari yang diperlukan beberapa mikrobiota untuk berfotosintesis. Endapan pasir atau lumpur yang terbawa air mempunyai dampak negatif dan dapat mengakibatkan menurunnya kehidupan biota laut. Kecerahan penting karena erat kaitannya dengan proses fotosintesis yang terjadi di perairan secara alami. Kecerahan menunjukan sampai sejauh mana cahaya 
dengan intensitas tertentu dapat menembus kedalaman perairan, dari total sinar matahari yang jatuh ke atmosfer dan bumi, hanya kurang dari $1 \%$ yang ditangkap oleh klorofil (di darat dan air), yang dipakai untuk fotosintesis.

Penelitian ini membuktikan bahwa keterkaitan antara persebaran klorofil - a terhadap kecerahan di perairan Pulau Sintok memiliki pola yang sama, yaitu pola divergen. Dimana persebaran klorofil - a dan kecerahan sangat dipengaruhi oleh kedalaman perairan dan garis pantai juga faktor fisika - kimia.

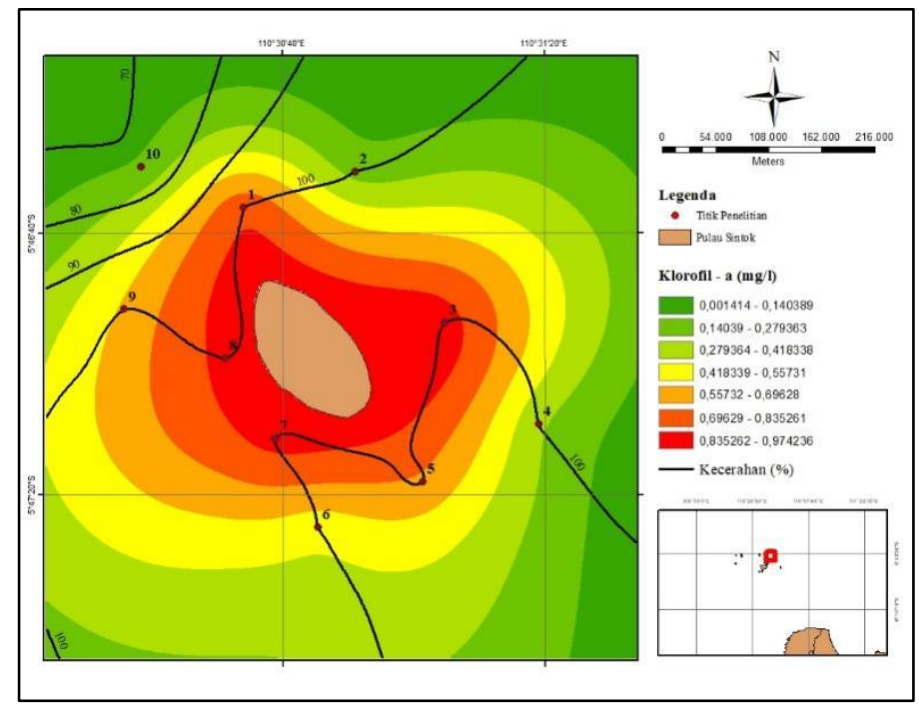

Gambar 5. Peta Overlay Klorofil-a dan Kecerahan

\section{Hubungan Klorofil-a dengan Derajat Keasaman (pH)}

Hubungan klorofil-a dengan $\mathrm{pH}$ terlihat signifikan. Hasil korelasi klorofil-a dengan $\mathrm{pH}$ menunjukkan bahwa klorofil-a dipengaruhi oleh $\mathrm{pH}$ yaitu sebesar $\mathrm{R}^{2}=0,9126$ (Gambar 9). Berdasarkan hasil overlay peta sebaran klorofil-a dan salintas, diperoleh bentuk pola divergen dari stasiun 1 sampai stasiun 10.

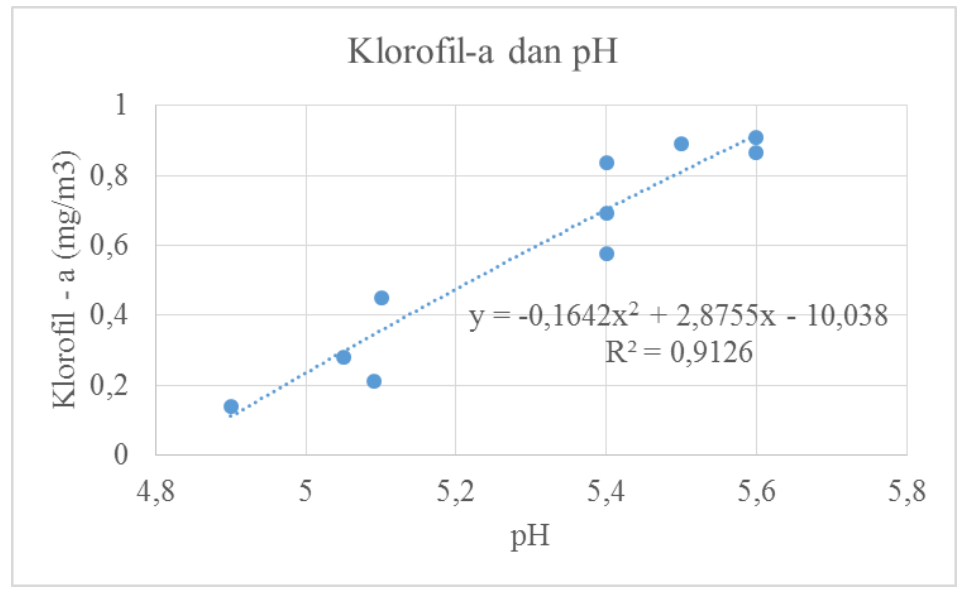

Gambar 6. Korelasi Klorofil-a dan pH

Derajat keasaman atu pH di perairan Pulau Sintok memiliki nilai konsentrasi sebesar 7 hingga 7,15. Nilai kisaran tersebut menunjukkan perairan tersebut tergolong baik untuk kehidupan biota laut dan mikrobiota seperti fitoplankton dan termasuk nilai yang optimum untuk perairan. Sesuai dengan KepMen LH No. 51 tahun 2004 tentang baku mutu air laut untuk biota laut, bahwa pH optimum bagi perairan sekitar 
7 - 8,5. derajat keasaman sebesar 0,9126 dan bersifat positif menunjukkan hubungan yang kuat antara kedua variabel tersebut. Nilai derajat keasaman juga sesuai dengan substrat dasar perairan Pulau Sintok yang merupakan pasir dan koloni terumbu karang yang melimpah sehingga mendukung kehidupan fitoplankton. Pernyataan tersebut diperkuat oleh hasil penelitian Sya'rani dan Suryanto (2006) yaitu derajat keasaman yang bersifat alkalis $(\mathrm{pH}>7)$ tersebut erat kaitannya dengan substrat dasar perairan yang merupakan rataan pasir dan terumbu karang sehingga kandungan garam biogenic khususnya kalsium $(\mathrm{Ca} 2+)$ cukup tinggi.

Hasil overlay antara dua variable yang menunjukkan pola sebaran divergen juga menunjukkan adanya pengaruh yang besar dari faktor fisika - kimia dan juga faktor kedalaman perairan. Hubungan yang erat ini berkaitan langsung dengan kemampuan fotosintesis fitoplankton yang mempengaruhi nilai $\mathrm{pH}$ di lokasi penelitian. Hal ini sesuai dengan penelitian Rifardi (2012), yang menyatakan bahwa proses biologi seperti fotosintesis mempengaruhi nilai $\mathrm{pH}$ di perairan karena proses ini membutuhkan $\mathrm{CO} 2$ yang diambil dari perairan.

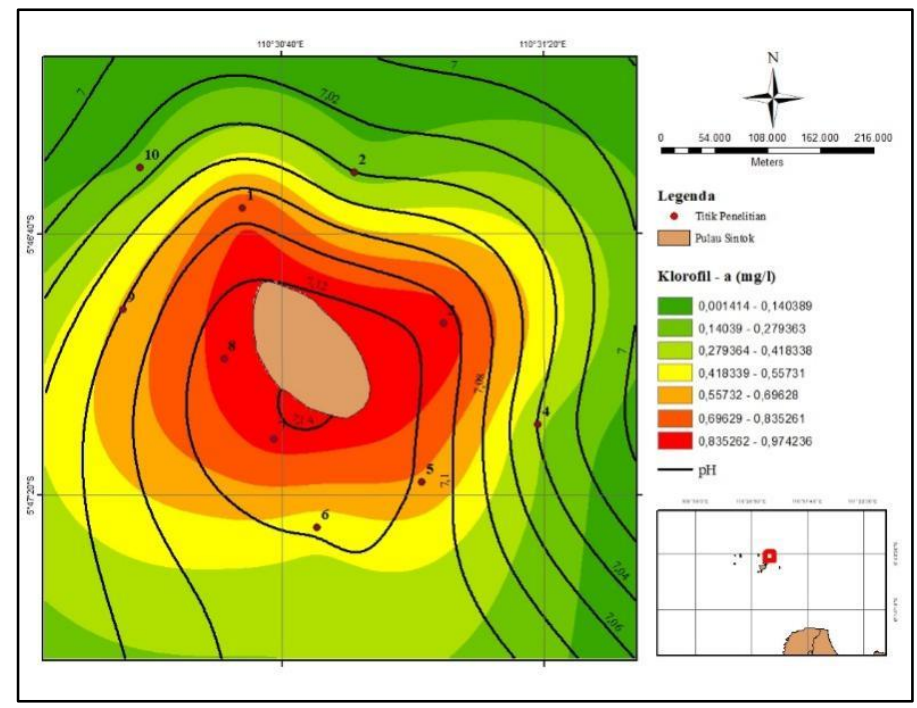

Gambar 7. Peta Overlay Klorofil-a dan $\mathrm{pH}$

\section{Hubungan Klorofil-a dengan Oksigen Terlarut (DO)}

Hubungan klorofil-a dengan DO terlihat signifikan. Hasil korelasi klorofil-a dengan DO menunjukkan bahwa klorofil-a dipengaruhi oleh DO yaitu sebesar $\mathrm{R}^{2}=0,9126$ (Gambar 11). Berdasarkan hasil overlay peta sebaran klorofil-a dan salintas, diperoleh bentuk pola divergen dari stasiun 1 sampai stasiun 10.

Kadar oksigen terlarut atau DO di perairan Pulau Sintok berkisar antara 4,9 mg/l - 5,6 mg/l (Tabel 3). Nilai DO pada perairan ini tergolong rendah, hal tersebut sesuai dengan pernyataan Ulqodry et al., (2010) bahwa secara umum kandungan oksigen terlarut di perairan Karimunjawa relatif rendah bila dibandingkan dengan kandungan umum oksigen terlarut yang dijumpai di perairan laut. Namun nilai tersebut masih tergolong normal untuk kehidupan dan proses metabolisme biota laut seperti fitoplankton sesuai dengan KepMen LH No. 51 tahun 2004 tentang baku mutu DO air laut untuk biota laut yaitu > 5 $\mathrm{mg} / \mathrm{l}$. Oksigen terlarut tentunya menjadi suatu faktor yang sangat berpengaruh untuk keberlangsusngan fotosintesis fitoplankton yang berhubungan langsung dengan persebaran klorofil - a di lokasi penelitian.

Nilai regresi antara klorofil - a dan oksigen terlarut di perairan Pulau Sintok cukup besar yaitu 0,9126 (Gambar 25). Nilai ini menunjukkan hubungan yang kuat antara klorofil - a dan DO, dimana proses fotosintesis itu sendiri membutuhkan oksigen. Hal ini sesuai dengan pernyataan Sastrawijaya (2001) yang menyatakan bahwa kadar oksigen terlarut berfluktuasi secara harian (diurnal) dan musiman, tergantung 
pada pencampuran (mixing) dan pergerakan massa air, aktivitas fotosintesis, tingkat penetrasi cahaya yang bergantung pada kedalaman dan kekeruhan air, jumlah bahan organik yang diuraikan dalam air seperti sampah, ganggang mati atau limbah industri dan respirasi yang masuk ke badan air. Diperkuat dengan pernyataan Effendi (2003) menerangkan bahwa, sumber oksigen terlarut dalam air adalah penyerapan oksigen dari udara, melalui kontak antara permukaan dengan udara, dan dari proses fotosintesis.

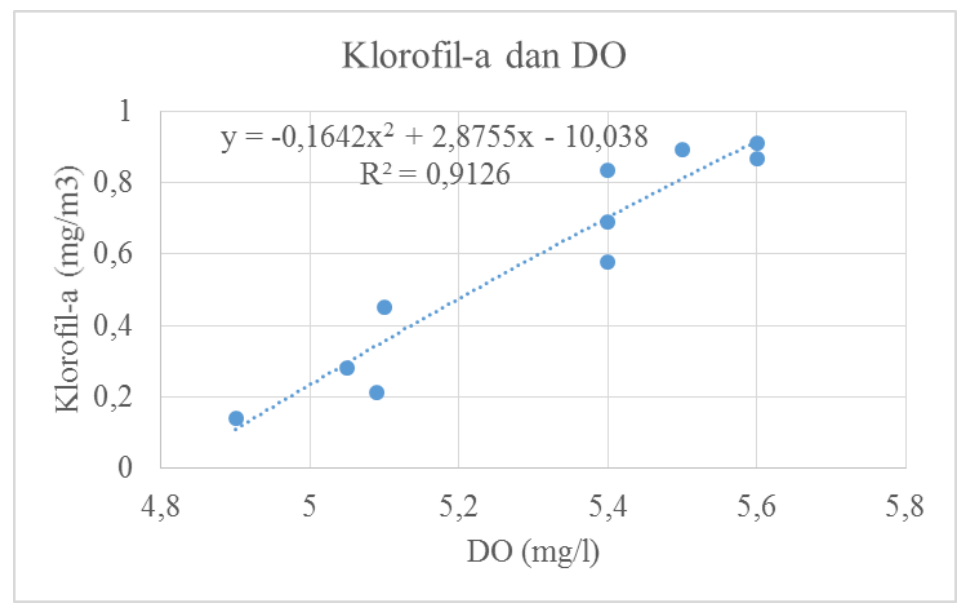

Gambar 8. Korelasi Klorofil-a dan DO

Hasil overlay klorofil - a terhadap DO menunjukkan pola persebaran yang sama yaitu divergen. Pola ini menunjukkan adanya pengaruh kedalaman perairan terhadap fluktuasi nilai dua variabel tersebut. Seperti yang di sajikan dalam Gambar 26, semakin bertambah kedalaman dan menjauhi bibir pantai, maka nilai klorofil - a dan DO akan semakin rendah. Hal ini diperkuat dengan pernyataan Salmin (2005) bahwa bertambahnya kedalaman, akan terjadi penurunan kadar oksigen terlarut, karena proses fotosintesis semakin berkurang dan kadar oksigen yang ada banyak digunakan untuk pernapasan serta oksidasi bahan - bahan organik. Keadaan tersebut membuktikan bahwa nilai DO di daerah pantai dan perairan laut tidak sama. Penelitian ini menunjukkan bahwa nilai klorofil - a dan DO berkaitan secara langsung dan dipengaruhi oleh beberapa faktor seperti kedalaman perairan, bibir pantai, dan juga beberapa faktor fisika - kimia.

\section{KESIMPULAN}

Berdasarkan hasil yang diperoleh dalam penelitian ini, maka diperoleh kesimpulan sebagai berikut:

1. Konsentrasi klorofil-a di perairan Pulau Sintok, Karimunjawa rata-rata sebesar 0,58588 mg/l, pola sebarannya adalah divergen.

2. Nilai kualitas air di perairan Pulau Sintok, Karimunjawa memiliki nilai rata-rata untuk suhu sebesar $28,77{ }^{\circ} \mathrm{C}$; salinitas sebesar 23,246\%; kecerahan sebesar 97,3\%; pH sebesar 7,089, DO sebesar 5,304, dengan pola sebarannya berbentuk divergen.

3. Hubungan klorofil-a dan kualitas air berdasarkan hasil overlay berbentuk divergen. Sedangkan nilai korelasi klorofil-a dan suhu sebesar $\mathrm{R}^{2}=0,7407$; klorofil-a dan salinitas sebesar $\mathrm{R}^{2}=0,8547$; klorofila dan kecerahan sebesar $\mathrm{R}^{2}=0,2758$; klorofil-a dan $\mathrm{pH}$ sebesar $\mathrm{R}^{2}=0,9126$; klorofil-a dan DO sebesar $\mathrm{R}^{2}=0,9126$

\section{DAFTAR PUSTAKA}

American Public Health Association [APHA]. 2012. Standard Methods for the Examination of Water and Waste Water. 22st ed. Washington (US): APHA.

Azis, M. F. 2007. Tipe Estuari Binuangeun (Banten) Berdasarkan Distribusi Suhu dan Salinitas Perairan. Oseanologi dan Limnologi di Indonesia, 33(1), 33-97. 
Effendi, H. 2003. Telaah Kualitas Air. Penerbit Kanisius. Yogyakarta. 50-72 hlm.

Handayani, S., \& Patria, M. P. (2010). Komunitas zooplankton di perairan waduk Krenceng, Cilegon, Banten. Makara Journal of Science, 9(2) : 75-80

Hutabarat, S dan Evans S. M. 2000. Pengantar Oseanografi. Jakarta: UI Press.

Koriyandi, A., Hamdani, H. and Salim, D., 2016. Analisis Kesesuaian Wisata Diving di Kawasan Perairan Pulau Kunyit Sebelah Timur Kecamatan Pulau Laut Tanjung Selayar Kabupaten Kotabaru. EnviroScienteae, 12(3): 181-193.

Nontji A. 2002. Laut Nusantara. Djambatan. Jakarta: 59-67 hlm.

Nybakken, J. W. 1992. Biologi Laut Suatu Pendekatan Biologis. PT Gramedia. Jakarta. 463 hlm.

Nuzapril, Mulkan., Susilo, Setyo Budi., Panjaitan, James P. 2017. Hubungan Antara Konsentrasi Klorofila dengan Tingkat Produktivitas Primer Menggunakan Citra Satelit Landsat-8. Jurnal Teknologi Perikanan dan Kelautan, 8(1): 105-114

Rifardi, 2012. Ekologi Sedimen Laut Modern Edisi Revisi. Pekanbaru. UNRI Press: Edisi Revisi Januari 2012

Riyono, S.H. 2007. Beberapa Sifat Umum dari Klorofil Fitoplankton. Pusat Penelitian Oseanologi-LIPI, Jakarta, 32 (1): 23-31.

Salmin, 2005. Oksigen Terlarut (DO) dan Kebutuhan Oksigen Biologi (Bod) sebagai Salah Satu Indikator untuk Menentukan Kualitas Perairan. Jurnal Oseana, 30(3): 21-56.

Sanusi, H. 2004. Karakteristik Kimia dan Kesuburan Perairan Teluk Pelabuhan Ratu pada Musim Barat dan Timur. Jurnal Ilmu-Ilmu Perairan dan Perikanan Indonesia IPB Bogor, 11(2): 93-100.

Sastrawijaya. 2001. Perencanaan Lingkungan. Penerbit: PT. Rineka Cipta, Cetakan kedua, Jakarta.

Suryanti. 2010. Degradasi Pantai Berbasis Ekosistem di Pulau Karimunjawa. Program Pascasarjana Universitas Diponegoro, Semarang. $38 \mathrm{hlm}$.

Sya'rani, L. dan Suryanto, A. 2006. Gambaran Umum Kepulauan Karimunjawa. Unisula Press, Semarang.

Utami, T. M. R., L. Maslukah dan M. Yusuf. 2016. Sebaran Nitrat (NO3) dan Fosfat (PO4) di Perairan Karangsang Kabupaten Indramayu. Jurnal Bulletin Oseanografi, 13(1): 31 - 37.

Ulqodry, T. Z., Yulisman, Syahdan, M. dan Santoso. 2010. Karakteristik dan Sebaran Nitrat, Fosfat dan Oksigen Terlarut di Perairan Karimunjawa, Jawa Tengah. Jurnal Penelitian Sains, 13(1): 35 - 41.

Zulfia, N dan Aisyah. 2013. Status Trofik Perairan Rawa Pening Ditinjau dari kandungan Unsur Hara (NO3 dan PO4) serta klorofil-a. Pusat Penelitan Pengelolaan Perikanan dan Konservasi Laut Bawal, 5(3): $189-199$ 